\title{
Increased productivity, role in alleviating food insecurity possible
}

Response \#1 to Hallsworth and Wong's viewpoint, "Urban gardening: A valuable activity, but..."

Kathryn Colasanti * and Michael Hamm

Michigan State University Center for Regional Food Systems

Submitted January 31, 2013 / Published online March 25, 2013

Citation: Colasanti, K., \& Hamm, M. (2013). Increased productivity, role in alleviating food insecurity

possible. Journal of Agriculture, Food Systems, and Community Development, 3(2), 15-16.

http://dx.doi.org/10.5304/jafscd.2013.032.011

Copyright (C) 2013 by New Leaf Associates, Inc.

It's true that urban agriculture may provide a modest contribution to most cities' food supply. However, Hallsworth and Wong (2013) fail to recognize the range of cities across North America as well as the numerous opportunities to increase the productivity of urban agriculture and its potential role in alleviating food insecurity. They also underemphasize the value of urban agriculture beyond the quantity of food produced.

There are many cities - Detroit, Cleveland, and Milwaukee come to mind - with large amounts of open space and notions of incorporating agriculture into the fabric of a $21^{\text {st }}$ century green city. The authors fail to acknowledge the potential for expanded productivity per unit of land beyond what is currently observed, for example with the use of passive solar, season-extension methods. In Michigan, with average low temperatures below Vancouver's, unheated hoophouses allow for at

* Corresponding author: Kathryn Colasanti, 480 Wilson Road, Center for Regional Food Systems, Natural Resources Room 303, Michigan State University, East Lansing, Michigan 48824 USA; colokat@msu.edu least 30 crops to be grown, many year-round (Colasanti, Matts, Blackburn, Corrin, \& Hausler, 2010). The authors dismiss what can be grown in a 4-square-meter (43-square-feet) garden as "suitable only for... personal enjoyment," but during the frost-free period an extra vegetable serving for a family of four per day is easily accomplished in this space.

The authors assume that more capital-intensive forms of urban agriculture are incompatible with food security due to cost. However, examples like sliding scale prices to serve both high-end restaurants and low-income customers exist. They also state that commercial, large-scale forms of urban agriculture would lose their "inherent localness." Yet "local" implies only geographic proximity, not scale. Commercial urban agriculture retains the potential for the community to obtain fresher food, connect with production, and establish a food system that is connected to their region, nation, and the globe, and is compatible with their values.

Ultimately, while there are places with population densities well below, and available vacant land 
well above, the authors' example of Vancouver (see above), highlighting either end of the urban density spectrum merely points to the insufficiency of generalizing. The number of people responsible for garden plots is likewise an inadequate gauge of urban agriculture's worth. Not only do garden plots likely serve multiperson households, but, more importantly, urban gardens provide value to the broader community - aesthetic and social value to the surrounding neighborhood, educational value to a nearby school, and recreational value to community youth groups. While a garden probably doesn't supply all food needs, research shows that gardening increases consumption of healthy, fresh produce (Alaimo, Packnett, Miles, \& Kruger, 2008), a key dietary improvement strategy.

We reject the implied premise that because urban agriculture doesn't encapsulate the solution for food security, it shouldn't be part of the toolkit (as well as the premise that because farmers' markets cannot supply all a city's population, they aren't worthwhile). While we would certainly argue for expanded resources to address the fundamental causes of food insecurity, in an era of economic austerity, we would also argue for maintaining the current investments in urban agriculture strategies that improve food security for participating households. We would furthermore argue for expanding urban agriculture's role in a number of our urban areas.

\section{References}

Alaimo, K., Packnett, E., Miles, R. A., \& Kruger, D. J. (2008). Fruit and vegetable intake among urban community gardeners. Journal of Nutrition Education and Behavior, 40(2), 94-101. http://dx.doi.org/10.1016/i.jneb.2006.12.003

Colasanti, K., Matts, C., Blackburn, R., Corrin, S., \& Hausler, J. (2010). Putting Michigan produce on your menu: How to buy and use Micbigan produce in your institution. East Lansing, Michigan: C. S. Mott Group for Sustainable Food Systems, Michigan State University. Available from http://foodsystems.msu.edu/resources/miproduce-institution

Hallsworth, A., \& Wong, A. (2013). Urban gardening: A valuable activity, but... Journal of Agriculture, Food Systems, and Community Development, 3(2), 11-14. http://dx.doi.org/10.5304/jafscd.2013.032.010 